\title{
Reposisi Ekspor Provinsi Kepulauan Riau Sebelum Dan Saat Terjadinya Pandemi Covid' 19 Tahun 2018 - 2020
}

\author{
Akhirman \\ Fakultas Ekonomi Universitas Maritim Raja Ali Haji, \\ Tanjungpinang, Provinsi Kepulauan Riau, Indonesia.
}

\begin{abstract}
ABSTRAK :Penelitian ini bertujuan untuk menlitia kebijakan pemerintah dalam upaya membuat kebijakan tentang Reposisi Eskpor Provinsi Kepulauan Riau tahun 2019-2020 atau sebelum dan pada masa terjadinya Wabah Covid'19 dan kebijakan pemerintah terhadap perekonomian nasional, serta daerah di Indonesia. Data yang digunakan untuk menganalisis penelitian ini adalah Data Sekunder, yang mana data ini diperoleh dari beberapa instansi seperti BPS Keepri, media di laman online yang memberikan informasi mengenai perekonomian yang terjadi saat pandemi covid-19 di indonesia dan daerah yang di keluarkan oleh pemerintah. Terutama untuk para eksportir serta pemerintah daerah lebih mementingkan kesehatan masyarakat luas dengan cara mengikuti himbauan pemerintah dengan salah satu cara adalah mengikuti lockdown hingga diterapkannya PSBB dengan tujuan agar dapat mencegah rantai penyebaran pandemi covid19.
\end{abstract}

Kata kunci: Perkembangan, Ekspor, Provinsi Kepulauan Riau, Pandemi’19.

\begin{abstract}
This study aims to committee government policies in an effort to make policies on the Export Repositioning of Riau Islands Province in 2019-2020 or before and during the Covid19 outbreak and government policies on the national and regional economies in Indonesia. The data used to analyze this research is secondary data, which is obtained from several agencies such as BPS Keepri, media on online pages that provide information about the economy that occurred during the Covid-19 pandemic in Indonesia and areas issued by the government. Especially for exporters and local governments who are more concerned with the health of the wider community by following the government's appeal in one way is to follow the lockdown until the implementation of the PSBB with the aim of preventing the chain of spread of the Covid-19 pandemic.
\end{abstract}

Keynote : Development, Export, Riau Island Province, Pandemic' 19

Email Address : 4akhirman@gmail.com 


\section{Pendahuluan}

\subsection{Latar belakang masalah}

Provinsi Kepulauan Riau adalah salah satu Provinsi sebagai daerah Industri, daerah perdagangan Internasional (Ekspor), sedikitnya ada 11 jenis komoditi (Type of Commodity) yang tergolong sebagai komodity ekspor dari Provinsi Kepulauan Riau ke Luar Negeri seperti tujuan Negara Singapura dan Malaysia, Jepang, Amerika Serikat, da China. Menurut Marolop Tanjung (2011:63), Ekspor adalah pengeluaran barang dari daerah pabeanan Indonesia untuk dikirim ke luar negeri dengan mengikuti ketentuan yang berlaku terutama mengenai peraturan kepabeanan.

Selain sebagai daerah Industri, Provinsi Kepulauan Riau juga merupakan wilayah strategis karena berada pada jalur lintas perdagangan Internasional, dan wilayah yang berbatasan langsung dengan Negara Singapura dan Malaysia, memiliki hubungan erat dan saling ketergantungan dalam bidang perdagangan antar Negara. Ada 11 jenis komodity ekspor asal Kepulauan Riau, yatu; Bahan bakar mineral, Mesin/peralatan listrik, mesin-mesin/pesawat mekanik, Minyak dan lemah hewan, Berbagai produk kimia, Benda-benda dari besi dan Baja, Kokoa/Coklat, Kapal Laut, Plastik an Barang-barang dari plastik, Perangkat Optik dan lainnya yang merupakan komodity ekspor Kepulauan Riau ke Singapura dan Malaysia.

Selain memiliki dampak positif juga tidak terlepas dari dampak negativ yang dengan cepat berpengaruh, apakah persoalan politik, perdagangan, krisis global, yang dapat mengganggu hubungan bilateral anta Negara, atau karena bencana alam, seperti kasus mewabahnya Pandemi Covid'19 yang awalnya berasal dari Kota Wuhan, Hubei,
Tiongkok pada tanggal 1 Desember 2019, telah merubah tatanan kehidupan sosial seluruh masyarakat termasuk kegiatan pada sektor perdagangan antar negara. Pemerintah sudah membuat berbagai kegijakan agar sektor ekonomi tetap stabil, baik melalui pemberian subsidi bantuan langsung kepada masyarakat, memberikan fasilitas restrukturisasi pembayaran hutang bagi badan usaha, memberikan keringan pajak, dan sebagainya.

Ekspor oleh setiap Negara di dunia adalah sesuatu yang penting untuk di kelola, di pertahankan, dan di jaga keberlangsungannya, karena berdasarkan pengertianya saja ekspor bermakna proses transportasi berbagai macam barang atau komoditas dan jasa yang diproduksi di dalam negeri atau suatu negara lalu dijual ke negara lain, proses ini seringkali digunakan oleh perusahaan dengan skala bisnis kecil sampai menengah sebagai strategi utama untuk bersaing di tingkat internasional. Ditinjau dari sudut pengeluaran, ekspor merupakan salah satu faktor terpenting dari Produk Domestik Bruto (PDB)/Gross Nasional Product (GNP), sehingga dengan berubahnya nilai ekspor maka pendapatan masyarakat secara langsung juga akan mengalami perubahan. Di lain pihak, tingginya ekspor suatu negara akan menyebabkan perekonomian tersebut akan sangat sensitif terhadap keguncangankeguncangan atau fluktuasi yang terjadi di pasaran internasional ataupun di perekonomian dunia.

Istilah Ekspor menurut Marolop (2011:63), “Ekspor adalah pengeluaran barang dari daerah pabeanan Indonenesia untuk dikirim ke luar negeri dengan mengikuti ketentuan yang berlaku terutama mengenai peraturan kepabeanan".Ekspor juga berarti pengiriman barang dan jasa dari pelabuhan suatu negara. Penjual barang dan jasa tersebut 
disebut sebagai eksportir dan berbasis di negara pengekspor sedangkan pembeli berbasis di luar negeri disebut sebagai importir. Dalam perdagangan internasional, ekspor mengacu pada menjual barang dan jasa yang diproduksi di dalam negeri ke pasar lain (Joshi, 2005, Jhingan, 2010, Bishop et al., 2014).

Sedangkan menurut Undang-Undang No. 10 Tahun 1995 tentang kepabeanan, Ekspor adalah kegiatan mengeluarkan barang dari Daerah pabean, dan barang yang telah diangkut atau akan dimuat di sarana pengangkut untuk dikeluarkan dari daerah pabean dianggap telah ekspor.

Ekspor adalah kegiatan mengeluarkan barang dari daerah pabean. Daerah Pabean adalah wilayah Republik Indonesia yang meliputi wilayah darat, perairan dan ruang udara di atasnya, serta tempat-tempat tertentu di Zona Ekonomi Ekslusif dan Landas Kontinen yang didalamnya berlaku Undang Undang Kepabeanan. Barang ekspor adalah barang yang dikeluarkan dari daerah pabean.

Pengertian menurut BEA CUKAI, yaitu lembaga yang bersesntuhan langsung dengan aktivitas Eksportir menyebutkan bahwa Ekspor adalah orang yang melakukan kegiatan mengeluarkan barang dari daerah pabean. Pemberitahuan pabean ekspor adalah pernyataan yang dibuat oleh orang dalam rangka melaksanakan kewajiban kepabeanan dibidang ekspor dalam bentuk tulisan di atas formulir atau data elektronik. Bentuk dan isi pemberitahuan pabean ekspor ditetapkan oleh Menteri Keuangan c.q. Direktur Jenderal Bea dan Cukai. Nota Pelayanan Ekspor yang selanjutnya disingkat dengan NPE adalah nota yang diterbitkan oleh Pejabat Pemeriksa Dokumen Ekspor atau Sistem Komputer Pelayanan atas PEB yang disampaikan, untuk melindungi pemasukan barang yang akan diekspor ke Kawasan Pabean dan/atau pemuatannya ke sarana pengangkut.

Sementara menurut Kantor Pabean adalah Kantor Pelayanan Utama Bea dan Cukai dan Kantor Pengawasan dan Pelayanan Bea dan Cukai tempat dipenuhinya kewajiban pabean. Kawasan Pabean adalah kawasan dengan batas-batas tertentu di pelabuhan laut, bandar udara, atau tempat lain yang ditetapkan untuk lalu lintas barang yang sepenuhnya berada di bawah pengawasan Direktorat Jenderal Bea dan Cuka.

Atas dasar uraian di atas serta keraguan apakah bahwa Pademi Covid'19 benar-benar membawa perubahan serta berdampak pada berbagai sektor termasuk sektor perdagangan di Indonesia dan khususnya Provinsi Kepualaun Riau yang jarak Kota Batam sebagai Pusat Industri dengan Singapura yang dapat di tempuh dengan waktu 45-60 menit memiliki dampak besar terhadap perdagangan pada wilayah Kepri - Singapura, dimana selama ini hubungan perdagangan Negara perbatasan memberikan andil besar terhadap pertumbuhan ekonomi nasional Indonesia dan daerah Kepulauan Riau sendiri.

\subsection{Tujuan Penelitian}

Penelitian ini berujuan untuk :

1) Mengetahui perkembangan ekspor Propinsi Kepulalaun Riau sebelum masa Pandemi Covid'19 atau tahun 2018

2) Mengetahui jenis ekspor Provinsi Kepulauan Riau tahun 2018-2020 yang tetap di jaga oleh pemerintah selema masa Pandemi Covid'19.

3) Mengetahui kebijakan pemerintah terhadap kegiatan ekspor Provinsi Kepulauan Riau Sejak Pandemi Covid'19 


\subsection{Manfaat Penelitian}

Adapun manfaat penelitian ini terutama

1) Bagi peneliti, penelitian ini berbuna untuk menambah pengetahuan, informasi, dan data terkait perkembangan ekspor daerah sebelum dan setelah ada bencana alam (wabah).

2) Agar semua elemen masyarakat mengetahui dan turut menjaga produktivitas pada jenis-jenis komoditas tertentu yang dapat terus melakukan aktivitas ekspor.

3) Bagi pemerintah, agar mampuu membuat kebijakan-kebijakan yang dapat membuat kegiatan ekspor dan impor tetap berjalan normal.

\section{Metode Penelitian}

Sistematik review berdasarkan jurnal menggunakan analisis deskriptif kualitatif. Dengan cara mendeskripsikan fenomenafenomena yang terjadi akibat dampak virus corona (Covid-19) terhadap perkembanagan ekspor di Provinsi Kepulauan Riau.

1. Lokasi penelitian, penelitian dilaksanakn di walayah Provinsi Kepulauan Riau.

2. Lama penelitian, penelitian ini meggunakan informasi, dan data perkembangan ekspor dari tahun 2018-2020 atau (tiga tahun).

3. Data diperoleh dari informasi, litetarur, dan data dari BPS Kepri, (2018-2020).

\section{Hasil dan Pembahasan}

\section{1) Perkembangan Ekspor Kepri secara kumulatif (2019-2020)}

Ada 2 (dua) jenis ekspor Provinsi Kepulauan Riau, yaitu ekspor Migas dan Non Migas. Untuk mengetahui trend dari kedua jenis pada ekspor tahun 2019-2020 tersebut dapat di ketahui dari tabel berikut ini.

Tabel 1.

Perkembangan Ekspor Barang dari Provinsi Kepulauan Riau (2018-2020)

\begin{tabular}{|c|c|c|c|}
\hline No & \multicolumn{3}{|c|}{$\begin{array}{c}\text { Ekspor Pada Bulan Februari } \\
\text { (jutaan US\$) }\end{array}$} \\
\cline { 2 - 4 } & 2018 & 2019 & 2020 \\
\hline 1 & 13192949035,00 & 12789650895,00 & 12006080990,00 \\
\hline
\end{tabular}

Sumber : BPS Kepri, (2020)

Dari tabel di atas dapat dijelaskan bahwa nilai ekspor dari Provinsi Kepulauan Riau dari tahun 2018 kepada tahun 2019 menunjukkan terjadi penurunan sebesar 403.298.140 juta US\$ atau turun 3,06 persen, kemudian pada tahun 2020 masih terjadi penurunan sebesar 783.569.905 juta US\$ di bandingkan antara tahun 2019 dengan tahun 2018. penurunan 3,06 persen. Penurunan ekspor tahun 2019 disebabkan terjadinya penurunan dari sektor Migas sebesar 12,58 persen atau senilai US\$ 519,75 juta. Namun pada sektor non migas mengalami kenaikan sebesar 1,29 persen atau senilai US\$ 116,45 juta dari tahun 2018. Sewaktu pada tahun 2018 nilai ekspor Kepulauan Riau pada Negara tujuan telah mengalami kenaikan 8,30 persen dari tahun 2017 yang baru berjumlah 12.182,03 juta US\$. Kenaiktan ekspor tahun 2018 disebabkan terjadinya kenaikan ekspor di sektor Migas sebesar 19.95 persen atau naik senilai 323,74 juta US\$ dari tahun 2017. 
2) Perkembangan Ekspor Provinsi Kepualauan Riau berdasarkan Jenis Komoditas Teratas.

Untuk mengetahui jenis Komoditi yang paling berpengaruh, serta komoditi apa

Tabel 4.

Perkembangan Nilai Ekspor Kepulauan Riau Tahun 2018-2019-2020

Berdasarkan Jenis Komoditi (Jutaan US\$)

\begin{tabular}{|c|c|c|c|c|}
\hline \multirow[t]{2}{*}{ No } & \multirow[t]{2}{*}{ Jenis Komoditi } & 2018 & 2019 & 2020 \\
\hline & & $\begin{array}{c}\text { Nilai } \\
\text { (Juta US\$) }\end{array}$ & $\begin{array}{c}\text { Nilai } \\
\text { (Juta US\$) }\end{array}$ & $\begin{array}{c}\text { Nilai } \\
\text { (Juta US\$) }\end{array}$ \\
\hline 1 & Bahan Bakar Mineral & 4.595 .01 & $1,627,00$ & 191,46 \\
\hline 2 & Mesin Peralatan Listrik & $2.690,00$ & $2.539,00$ & $2.083,12$ \\
\hline 3 & Mesin-mesin/Pesawat Mekanik & $1.046,00$ & 900,00 & 89,30 \\
\hline 4 & Minyak dan Lemah Hewan & 932,00 & 849,00 & 5,25 \\
\hline 5 & Benda-benda dari Besi dan Baja & 593,00 & 484,00 & 36,92 \\
\hline 6 & Berbagai produk kimia & 504,00 & 310,00 & \\
\hline 7 & Kokoa/Cokelat & 321,04 & 301.47 & 15,91 \\
\hline 8 & Kapal laut & & 245,08 & 2,14 \\
\hline 9 & Perangkat Optik & 232,21 & 238,72 & 20,57 \\
\hline 10 & Plastik dan barang dari plastik & 180,39 & 234,92 & 19,46 \\
\hline 11 & Sari bahan samak dan celup & 168,63 & 146.16 & - \\
\hline 12 & Timah & 162.51 & 145,72 & - \\
\hline 13 & $\begin{array}{l}\text { Minyak atsiri, Kosmetik wangi- } \\
\text { wangian }\end{array}$ & 156.87 & 145.98 & - \\
\hline 14 & Kendaraan dan bagiannya & 155,47 & 147,31 & - \\
\hline 15 & Bahan kimia optik & 142,54 & 142,15 & - \\
\hline 16 & Barang-barang rajutan & 130,56 & 130,09 & - \\
\hline 17 & Mainan & 102,09 & 102,98 & - \\
\hline 18 & Besi dan Baja & - & 6839 & - \\
\hline 19 & Babi Potong & - & 797,3 & 987,7 \\
\hline 20 & Karet dan barang dari karet & - & 57,38 & \\
\hline 21 & lainnya & 719,34 & 453,35 & 109,95 \\
\hline
\end{tabular}

Sumber : BPS KEPRI, (2020)

Dari tabel di atas dapat dijelaskan selama tahun 2018-2020 ada 6 besar Komoditi ekspor dari Provinsi Kepulauan Riau yang selama 3 ( tiga tahun ) memiliki nilai ekspor tertinggi, yaitu mulai dari Bahan Bakar Mineral tahun 4.595.01 juta US\$, sementara pada tahun 2019 terlihat saja yang tetap dipertahankan dan eskspornya tetap berjalan dari 11 komoditi di atas, khususnya antara tahun 2018 - 2020 adalah : 
penurunan dengan nilai ekspornya hanya $2.083,12$ jutaa US\$.

Mesin-mesin/Pesawat Mekanik pada tahun 2018 dengan nilai ekspor sebesar 1.046 juta US\$, kemudian pada tahun 2019 turun dengan nilai 900 juta US\$, selanjutnya pada tahun 2020 ekspor m/sin pesawat mekainik ini turun lebih drastis dan hanya memiliki nilai 89,30 juta US\$. Selanjutnya adalah Minyak dan Lemah Hewan nilai ekspor pada tahun 2018 berjumlah 932 juta US\$, pada tahun 2019 nilai ekspornya turun menjadi 849 juta US\$, dan tahun 2020 ekspor Minyak dan lemah Hewan nilai ekspornya hanya 5,25 juta US\$.

Untuk Komoditi Benda-benda dari Besi dan Baja nilai ekspor pada tahun 2018 adalah sebesar 593 juta US\$, sedangkan pada tahun 2019 nilai ekspornya berjumlah 484 juta US\$ dan pada tahun 2020 nilai ekspornya turun sangat jauh yaitu 36,92 juta US\$. Demikian juga Komoditi ekspor berbagai produk Kimia pada tahun 2018 total nilai ekspornya 504 juta US\$, sementara pada tahun 2019 berjumlah 310 juta US\$, sementara pada tahun 2020 tidak ada ekspor untuk komoditas berbagai produk Kimia dimaksud.

Pada tahun 2019 terdapat adanya ekspor Babi Potong yang cukup tinggi dengan nilai ekspornya 797,3 miliyar. Dan pada tahun 2020 terjadi peningkatan terhadap ekspor Babi Potong yaitu dengan total nilai ekspornya mencapai 987,7 miliyar rupiah.

Dengan data dan keterangan di atas, dapat disimpulkan bawah; Covid'19 berdampak terhadap kegiatan ekspor dari Kepulauan Riau khususnya sejak akhir tahun 2019 sampai tahun 2020 .

\section{3) Reposisi}

Arti kata, ejaan, dan contoh penggunaan kata "reposisi" menurut Kamus Besar Bahasa Indonesia (KBBI). Berikut ini makna dan tulisan kata reposisi yang benar: re·po·si.si /réposisi/ n penempatan kembali ke posisi semula; penataan kembali posisi yg ada; penempatan ke posisi yg berbeda atau baru.

Khusus untuk istilah dari Reposisi, pada tahun 2017 ketika ekonomi global bermasalah pemerintah Indoensia melalui menteri Pedangan sudah pernah melakukan kebijakan yaitu reorientasi dan reposisi bidang perdangan. Untuk menghadapi krisis keuangan global, pemerintah dalam hal ini menteri perdangan akan mengimplementasikan kebijakan meningkatkan perwakilan perdagangan, baik Atase Perdagangan (Atdag) maupun Indonesian Trade Promotion Center (ITPC) agar lebih proaktif menjadi agen bisnis, serta meninjau lokasi dan perluasan wilayah kerja negara terakreditasi. Untuk meningkatkan peran sebagai agen bisnis, pada waktu itu telah disusun 10 produk andalan, 10 pembeli potensial, dan 10 penjual potensial; menetapkan strategi pemasaran dengan perimbangan antara mempertahankan pasar lama dan mencari pasar baru, business intelligence, pemahaman dan penanganan hambatan teknis perdagangan dan trade remedies secara cepat, serta menyusun rencana aksi promosi. Di sinilah menjadi relevan kebutuhan mengubah pola pikir dari agen pemerintah menjadi agen bisnis yang proaktif, inovatif dan berorientasi solusi," Strategi pengembangan perdagangan internasional juga memberi perhatian pada partisipasi UKM. Kemendag akan melakukan penguatan UKM orientasi 
ekspor melalui diklat ekspor, program pendampingan (coaching program), pemanfaatan ekonomi digital, dan customer service center (CSC).

Kebijakan pemerintah membuat kebijakan terhadap berbagai kegiatan bukan saja Indoensia, namun seluruh Negara melakukan hal yang sama. Mungkin sebahagian orang menyebutnya bahwa kebijakan ini berdampak terhadap ekonomi, namun pemerintah memiliki pertimbangan dampak PANDEMI ini terhadap kesehatan masyarakat lebih utama daripada kegiatan lainnya. Beberapa kebijakan pemerintah yang ada hubungannya dengan kegiatan ekonomi, serta beban masyarakat dan lembaga ekonomi swasta pemerintah sudah menetapkan setiaknya 6 kebijakan, yaitu :

1. Kemudian Kemenkeu memberikan empat jenis insentif pajak terkaitketentuan Pajak Penghasilan $(\mathrm{PPh})$ pasal 21, PPh pasal 22 impor, PPh pasal 25dan Pajak Pertambahan Nilai (PPN). Insentif $\mathrm{PPh}$ Pasal 2 diberikan kepada pemberi kerja sesuai klasifikasi 440 lapangan usaha yang tercantum padalampiran PMK 23/2020

2. Pemerintah memberikan insentif pengurangan Angsuran $\mathrm{PPh}$ Pasal 25 sebesar $30 \%$ dari angsuran yang seharusnya terutang. Pengurangan besarnyaangsuran $\mathrm{PPh}$ Pasal 25 dilakukan dengan menyampaikan pemberitahuan penguranganbesarnya angsuran secara tertulis kepada Kepala KPP tempat WP terdaftar. Jlka kriteria WP untuk pemberian insentif terpenuhi maka pengurangan besarnya angsuran akan berlaku sampai dengan Masa Pajak September 2020 .
3. insentif PPN bagi WP yang memiliki klasifikasi lapangan usahaterlampir di PMK 23/2020 dan telah ditetapkan sebagai perusahaan KITE. Selainitu, Pengusaha Kena Pajak (PKP) ini adalah WP yang PPN lebih bayar restitusinya paling banyak $\mathrm{Rp} 5$ miliar. Pemerintah juga mempercepat prosesekspor dan impor untuk traders yang memiliki reputasi baik.

4. Upaya lain dari pemerintah di sektor pariwisata dengan pembebasan pajak hotel dan restoran, hal ini dilakukan dengan pembebasan pajak hotel dan restoranselama 6 bulan. Tetapi pembebasan pajak hanya terbatas pada 10 daerah wisatayaitu yaitu Danau Toba, Yogyakarta, Malang, Manado, Bali, Mandalika, LabuanBajo, Bangka Belitung, Batam, dan Bintan

5. Kebijakan ini juga mengharuskan pemerintah untuk menutup pelabuhan air dan udara yang menghambat distribusi barang antar negara. Laporan International Air Transport Association menunjukan penurunan kuantitas transportasi kargo internasional (belly-hold dan freighters) sampai dengan bulan Maret 2020 sebesar 23\% secara yearon-year dengan estimasi kerugian mencapai US\$1,6 miliar.

6. Lebih lanjut, keputusan negara untuk menerapkan pembatasan ekspor (export restrictions) demi melindungi pasokan domestik turut menambah kompleksitas permasalahan. World Trade Organization mencatat 80 negara dan otoritas kepabeanan telah menerapkan export restrictions atas perlengkapan medis, bahan pangan, serta kertas toilet termasuk didalamnya negara-negara yang 
menjadi 'lumbung' pangan dunia seperti Rusia, Vietnam, dan Argentina.

\section{4) Covid-19}

Covid-19 adalah suatu penyakit yang disebabkan oleh virus SARS CoV-2dan memiliki gejala yang mirip dengan flu biasa, yang dapat berlanjut pada sakit parah dan radang paru (Pneumonia), sehingga menyebabkan kesulitan bernafas.Organisasi Kesehatan Dunia (WHO), sebagai sumber acuan dunia dalam menghadapiCovid-19, telah merilis beberapa langkah-langkah perlindungan dasar individudalam menghadapi Pandemi ini. Beberapa diantaranya yaitu menjaga kebersihantangan melalui rajin cuci tangan dengan sabun dan air mengalir atau dengancairan berbasis alkohol, menjaga jarak sosial (Social distancing) dengan caramenjaga jarak setidaknya 1 meter dengan orang lain atau siapa saja yang batuk atau bersin, hindari menyentuh mata, hidung dan mulut, karena ketiganya merupakan jalan masuknya virus ke dalam tubuh, menjaga kebersihan pernafasan dengancara menutup mulut dan hidung dengan tisu atau dengan siku pada saat batukdan bersin, jika mengalami demam, batuk dan kesulitan bernafas, cari perawatan medis sesegera mungkin, serta tetap mencari informasi dan mengikutisaran yang diberikan oleh penyedia layanan kesehatan setempat.

Sejak kemunculannya pada Desember 2019 lalu pandemi Covid-19 telah menimbulkan dampak yang sangat serius pada hampirseluruh aspek kehidupan manusia di muka bumi,terutama di sektor ekonomi. Berdasarkan masalah tersebut, peneliti memiliki ketertarikan untuk meneliti apa sajadampak dari covid-19 terhadap perekonomian.Secara Makro, perubahan jumlah permintaan dan penawaran agregat akanmempengaruhi tingkat kegiatan perekonomian pada periode tertentu yang padagilirannya akan berpengaruh pula terhadap pendapatan nasional atau produksinasional (PDB-Produk Domestik Bruto). Salah satu yang menjadi indikator baik buruknya perekonomian disuatu daerah adalah dengan melihat tingkat pertumbuhanekonominya. Pertumbuhan ekonomi adalah persentase perubahan kegiatan ekonomi,yang salah satunya dapat diukur dari jumlah persentase perubahan produksi barang dan jasa. (Harmadi, n.d. dalam Maryanti,2020)

Dampak wabah virus Corona (Covid-19) tidak hanya merugikan sisi kesehatan.Bahkan virus ini turut mempengaruhi perekonomian negaranegara di seluruh dunia,tak terkecuali Indonesia. Ekonomi global mngalami penurunan, menyusul penetapandari WHO yang menetapkan wabah Corona sebagai pandemi yang mempengaruhidunia usaha.Virus corona mulai merebak disekitar wilayah Wuhan dan kini telahmenjangkiti lebih dari 100 negara. Semakin meluasnya wabah corona ke berbagai belahan dunia menjadi ancaman serius bagi perekonomian global. "Penyebaransemakin meluas akan memperlama periode jatuhnya perekonomian.

\section{Kesimpulan}

Beberapa kesimpulan yang dari penelitian ini dapat disampaikan adalah : 
1) Bahwa tahun 2019 jenis komoditi ekspor Bahan Bakar Minya dari Provinsi Kepulauan Riau 4.595.01 juta US\$ merupakan komoditi tertinggi, pada tahun 2020 turun menjadi 191,46 juta US\$. Demikian juga dengan komposisi ke 2 yaitu Mesin Peralatan Listrik dari 2.690, juta US\$ pada tahu 2018 turun menjadi 2.083 juta US\$ pada tahun 2020.

2) Sedangkan ekspor selama masa Covid'19 yang mengalami kenaikan adalah Komoditi Babi Potong dari 797,3 juta US\$ pada tahun 2019 ternyata pada tahun 2020 mengalami kenaikan yaitu 987,7 juta US\$.

3) Wabah Covid'19 sejak mulai Maret 2020 di Provinsi Kepuauan Riau telah merubah Posisi nilai ekspor dari 13192949035 juta US\$ tahun 2018 menjadi 12006080990 juta US\$. Sehingga sampai pada penelitian ini posisi nilai ekspor tersebut masih di bawah perkembnagna ekspor tahun sebelumnya.

4) Terdapat 9 kebijakan pemerintah yang di tuangkan melalui Instruksi Presiden Nomor 4 Tahun 2020, Tentang Refocussing Kegiatan, Realokasi Anggaran serta Pengadaan Barang dan Jasa dalam rangka Percepatan Penanganan Corona Virus Disease 2019.

\section{Daftar Pustaka}

Ahira, Anne. (2013), Artikel Perdagangan Internasional Ekspor Impor. Fromhttp:

//books.google.co.id/books/about/Per dagangan_Internasional_ekspor_imp or.html?id=KL3THQAACAAJ\&redi r_esc $=\mathrm{w}$

BPS Kepri, (2020), Perkembangan Ekpsor Migas dan Non Migas.
BPS Kepri, (2020), Perkembangan Ekpsor Kepulauan Riau berdasarkan Jenis Komodity.

Inpres. Nomor 4 Tahun 2020 tentang Tentang Refocussing Kegiatan, Realokasi Anggaran serta

Pengadaan Barang dan Jasa

dalam rangka Percepatan Penanganan Corona Virus

Disease 2019.

Joshi, 2005, Jhingan, 2010, Bishop et al., (2014). Pengertian ekspor barang dan jasa.

Maryanti, S., Netrawati, I.G.A. O., \& Nuada, I. W. (2020). Pandemi Covid-19 dan Implikasinya

Pada Perekonomian Ntb. Media Bina Ilmiah,14(10), 3497-3508

Tandjung, Marolop. 2011.Aspek dan Prosedur Ekspo - Impor JakartaSalemba Empat.

Undang-Undang No. 10 Tahun 1995, Tentang Pengertian Kepabeanan. 